\title{
Teaching Team Construction and Teaching Reform of the School of Communication Under the Background of New Liberal Arts - Taking Sichuan University of Media and Communications as an Example
}

\author{
Jialin Jin ${ }^{*}$, Dandan Ren ${ }^{2}$ \\ ${ }^{1}$ College of Communication and Management, Sichuan University of Media and Communications, Chengdu 611745, \\ Sichuan Province, China \\ ${ }^{2}$ School of Finance and Trade Management, Chengdu Industry and Trade College, Chengdu 611745, Sichuan Province, \\ China \\ *Corresponding author: Jialin Jin, 283163420@qq.com \\ Copyright: ( $) 2022$ Author(s). This is an open-access article distributed under the terms of the Creative Commons Attribution License (CC \\ BY 4.0), permitting distribution and reproduction in any medium, provided the original work is cited.

\begin{abstract}
Under the background of new liberal arts, in order to run a major well as well as highlight its characteristics and advantages, private colleges and universities cannot do without the construction of professional teaching teams and teaching reforms. Taking Sichuan University of Media and Communication as an example, a series of explorations and practices has been carried out from the aspects of professional team construction, personnel training objectives, professional curriculum system, professional teaching mode, and professional teaching quality, in which good results have been achieved. On this basis, a training base for journalism and communication talents serving the whole Sichuan Province and even the western region is constructed, so that the results of the project have a certain demonstration and promotion value for the construction and development of similar majors in new institutions of higher learning in Sichuan Province.
\end{abstract}

Keywords: New liberal arts; Communication; Teaching team; Teaching reform; Talent training program; Curriculum system

Online publication: January 20, 2022

In April 2019, 13 departments, including the Ministry of Education and the Ministry of Science and Technology, officially launched the "Six Excellence and One Top-Notch Program 2.0" to comprehensively promote the construction of new engineering, new medical, new agricultural sciences, and new liberal arts ${ }^{[1]}$. In November 2020, the work conference on the construction of new liberal arts was held at Shandong University. The Ministry of Education held important discussions about the situation of the era, development demands, and implementation paths of the construction of new liberal arts; a systematic and scientific theoretical system was proposed for the construction of new liberal arts, indicating that the construction of new liberal arts has entered a new stage.

The digital revolution and upgrading of the media industry have posed new challenges to the school of journalism and communication. Under the background of "new arts," developing joint communications and changing the application of transmission talents cannot be detached from the construction of professional teaching teams. It is imperative to give full play to the construction of teaching teams in the "new arts," and 
its important support role in the reform strategy can truly promote the cultivation of talents. Combined with the construction and reform of new liberal arts, the communication course in Sichuan University of Media and Communication has also made certain progress and achievements in regard to the construction of a teaching team. This paper will comprehensively sort out the construction of the teaching team and the teaching reform of the communication major, so as to facilitate peer reference and exchange.

First, in view of the insufficient number of teachers and the unreasonable structure of the teaching staffs, a new talent policy has been implemented - "Internal Training and External Introduction."

The communication major of Sichuan University of Media and Communications began to prepare for the application in 2006 and began recruiting students in the province after the application was successful in 2007. At the time of application, the major was positioned to cultivate innovative talents in journalism and communication. As teaching teams are an important part of modern university education, journalism and communication departments should naturally regard the construction of teaching teams as an important way to standardize teaching behavior, improve teaching level, and ensure the quality of talent cultivation ${ }^{[2]}$. Before September 2018, the teaching team of the communication major comprised of 7 full-time teachers, including 1 associate professor, 2 lecturers, and the others were teaching assistants; there were only 2 "double-qualified" teachers. With the upgrading and transformation of the media industry, the school of communication is preparing to carry out a new round of teaching reform based on the guiding ideology and overall development plan of the university. In particular, the goal and orientation of talent training have been restructured, aiming to cultivate students who can meet the needs of the developing communication industry and the industrial upgrading in western China. These include versatile communication talents with strong skills in party and government communication, cultural communication, new media communication, and media management. Therefore, the first step is to reform the teaching team, so as to build an excellent professional teaching team to support the cultivation of interdisciplinary communication talents.

Through the implementation of the new talent policy, the number of teaching teams of the communication major has reached 15 in total, having met the national standard in terms of the ratio of students to teachers. At the same time, the school of communication has established a professional teaching team led by renowned teachers in Sichuan Province and protected by industry mentors as well as front-line "double-qualified" full-time teachers. The team is reasonable in age structure and title. At present, the teaching team consists of 15 teachers, including 4 professors, 4 associate professors, and 7 lecturers. Among them, there is an outstanding teacher from Sichuan Province, a candidate for the academic and technological leadership role in Sichuan Province, another who has won provincial and ministerial teaching awards, and 6 who have acquired the title of "excellent teachers of the university." More than $65 \%$ of them are "doublequalified and double-capable" teachers, among which 8 are "double-qualified" teachers, all of whom have worked in enterprises corresponding to their professional positions, providing strong practical support for professional practical teaching, and achieving remarkable teaching results.

Second, the goal of talent training is not in line with the times and inadequately qualified for the industry. Therefore, the existing talent training program needs to be reconstructed.

The training program is the core of undergraduate talent training in the school of journalism and communication. It is an intuitive presentation of the interdisciplinary education concept and a detailed interpretation of curriculum setting and talent training objectives ${ }^{[3]}$. The goal of the 2017 edition is to cultivate talents to meet the needs of social, economic, and cultural development in the 21 st century, with all-around development in moral, intellectual, physical, and aesthetic aspects. These talents should be able to systematically master the operation mechanism and application skills of mass media, familiar with news communication policies and regulations, as well as skilled in using foreign languages and computers. In view of the current situation, the continuous development of new media has affected traditional media to some extent, bringing certain changes and challenges; in addition, the market for information dissemination 
is also in turmoil ${ }^{[4]}$. Therefore, the 2017 professional communication talent training target is the talent of education popularization of news media, and with the development of new media, the situation of traditional mass media will be in deep waters, if, the 2017 edition of talent training to cultivate talents of news dissemination does not conform to the trend of the development of modern media industry and change. Therefore, the target positioning of talent training needs to be revolutionized and in line with the needs and demands of the modern media industry, so as to better cultivate talents to meet the needs of the industry.

Based on the above situation, the teaching team of the communication major put forward a new talent training program (2021 version) by investigating and analyzing the industry and academics as well as carrying out a series of special seminars. Specifically, this major is based in Chengdu, facing Sichuan and radiating to southwest China. It focuses on cultivating applied compound communication talents to meet the development needs of the modern media industry. In the process of systematic learning, students should be equipped with Marxist perspectives and master socialist communication policies and regulations. On the basis of acquiring humanities and social science theories as well as professional knowledge on information communication, one can focus on mastering the ways and methods of information communication of various media and gain the ability of integrated communication as well as planning to meet the needs of the all-media era.

A comparison between the 2017 edition and the 2021 edition shows that there are obvious differences in the training goals of the two professional communication talent training programs. The new talent training program conforms to the development and changes in the industry, highlights the cross integration of disciplines and majors, as well as reflects the orientation of the university to adhere to the goal of application-oriented talent training.

Third, it is difficult to cultivate talents under the old curriculum system; therefore, it is urgent to develop a curriculum system that meets the demands of market employment and professional characteristics.

Multi-dimensional research on the construction of journalism and communication major under the new situation, with "composite training" and "applied education" as keywords, has been carried out. Sun Zhenhu believes that the in the construction of the curriculum system, talent training should be assumed as the goal, value guidance as the basis, and the curriculum construction as the starting point, while moving along the construction path of "integration," "crossing," "bearing," and "innovation."

Before the teaching reform, the curriculum system of the communication major in Sichuan University of Media and Communications still held on to traditional education ideas, which lacked the integration of new media content and disregarded the penetration of the interdisciplinary system. Therefore, the teaching team investigated more than 10 universities and 23 media employers nationwide as well as invited 23 experts from academia (including all members of the teaching team of the major) and the industry to hold 4 seminars on curriculum system reconstruction. The core theme of the conference is to optimize and perfect the curriculum system and solve the contradiction between the construction of "new liberal arts" and the training goal of applied compound communication talents in the context of integrated media as well as the relatively lagging curriculum system of traditional communication.

Based on the existing teaching concept, the characteristic "TTCO" curriculum system has been constructed. In other words, the complementary advantages of Sichuan University of Media and Communications in multi-disciplines have been assumed so as to create a curriculum system with theory $(\mathrm{T})$, technology $(\mathrm{T})$, creative $(\mathrm{C})$, and operation $(\mathrm{O})$ as the core. In this way, the complementary teaching of theory, practice, art, production, and employment can be formed to conform to the change and development trend of the era of integrated media.

Fourth, the traditional teaching mode cannot meet the application of modern professional teaching situations; therefore, it is imperative to break through the boundaries of the classroom, pay attention to the application of intelligent media, and form a new teaching form. 
In order to enhance the vision of the industry and the "outstanding journalism and communication talents" concept, it is necessary to explore the breakthrough of classroom boundaries and promote active learning on the basis of traditional classroom teaching, The first is by combining competition and training. By means of course assessment, professional competition credits, as well as hosting and co-organizing various professional competitions, competitions and trainings can be normalized and institutionalized. The second is by project teaching, which is carried out through the "order-type" project of counterpart media units, the simulation practice of rotation at internship base, especially massive media content research, as well as the reliance of the development platform on "Chengdu Film and Television Silicon Valley." The third is by second classroom. Through the establishment of media-type studios or school-run enterprises, the establishment of students' professional societies and interest groups as well as the teaching and training of the second classroom should be promoted.

In addition to curriculum construction, the major has also carried out in-depth reform in practice and training, building a practical teaching system that highlights application, the industry, and the times. With the strong support of the school, the laboratory of communication science now owns a number of professional photography equipments, including SONY NX-5 cameras, Canon SLR cameras, and others. New media content production equipment and facilities, integrating creativity, shooting, editing, and processing, such as key studios for radio and TV public service advertisement creation, film and television creation, as well as new media research and creation training studio, have been set up. This has become a strong backing for discipline practice and construction.

Fifth, the teaching system is not standardized, and the supervision system is flawed, without being able to guarantee the professional teaching quality. Therefore, it is imperative to construct a professional teaching quality barrier system.

Before the reform of professional teaching, the teaching system was not standardized and the supervision system was flawed, leading to a huge negative impact faced by the school of communication in talent training and teaching quality. Therefore, through the reform of professional teaching in the past five years, three measures have been drawn up to improve the quality of professional teaching. The first is to formulate a teaching system and establish quality standards. On the basis of professional orientation, curriculum standards and teaching outline are formulated to form standardized and rigorous quality standards. A number of evaluation standards and management systems should be formulated and implemented, such as "Undergraduate Teaching Management Standards," "Curriculum Quality Standards," "Graduation Thesis (Design) Standards," "Teachers' Annual Assessment Implementation Measures," to ensure a smooth teaching operation and good teaching quality. The second is to set up a supervising team and strengthen teaching inspection. Teaching supervision is an important link and key guarantee for colleges and universities to carry out national educational guidelines and policies, promote educational and teaching reform, as well as improve the quality of education and teaching ${ }^{[5]}$. A three-level supervision and guidance system, which involves university-level supervision, college-level supervision, and course group guidance, has been established. Regular teaching supervision and inspection, mutual lectures, as well as teaching and research activities have been carried out. A mid-term teacher-student teaching symposium is held every semester, and students' teaching evaluation is performed at the end of each semester, thus ensuring the teaching order and teaching quality.

Sixth, through the construction of the teaching team and a series of professional teaching reforms, the teaching reform has achieved remarkable results.

At present, the orientation and benefits of the major's project achievements are mainly reflected in the employment rate of graduates, students' practical skills, teachers' scientific research achievements, as well as the degree of evaluation and recognition of teaching achievements by peers and the industry. 
(1) High employment rate of communication students and satisfaction of employers.

Both graduate and professional employment rates are high; the employment rate for communication graduates in 2018, 2019, and 2020 is $100 \%$. In terms of external evaluation, the quality of graduates is categorized under "four satisfactions." The school of communication has carried out a follow-up survey on the quality of graduates for many years, forming a regular social evaluation mechanism. The results from the survey showed that the vast majority of graduates could adapt to their positions at work, and the quality of talent cultivation was "satisfied with students, parents, employers, and society." Employers gave high scores to graduates in terms of new media content production and planning ability; in addition, the job performance and competence of the graduates were $100 \%$ praised.

(2) The combination of competition and training greatly improves students' practical skills.

Since 2013, the school of communication has realized the normalization and popularization of competitions and trainings through the combination of competition and training by "promoting teaching through competition." In the mid-term, the participation rate of sophomore and junior communication students reached 100\%. Students have participated in the "New Media Creativity Competition," "Academy Award," "Big City Competition", "Sichuan Province Radio and TV Public Service Advertising Creation Competition," and other business planning competitions. The "New Media Creativity Competition," sponsored by the Education Department of Sichuan Province, is taken as an example. Since 2020, 184 participants have been organized and won 18-grade in the "New Media Creativity Competition" held by Sichuan Province.

(3) Carrying out teaching reform to promote scientific research.

The monographs of "Case Analysis and Research on Communication," jointly compiled by the team of teachers from the school of communication, have been transformed into teaching materials. The general textbooks of journalism and communication, such as "Introduction to Communication" and "New Media Copywriting," are being compiled. Meanwhile, the school is also preparing for the recording of MOOCs for this course, which will be promoted to the whole school and even the whole country upon successful recording. In the past five years, the members of the teaching team have been researching 6 provincial projects and have published 26 papers, among which 8 are included in CSSCI and 3 in Peking University.

In conclusion, with the construction and development of "new liberal arts" as well as the deepening of education and teaching reform, the school of communication must consider the quality of talent cultivation, adapt to the employment needs of the modern media industry, and regularly carry out research on a series of industry talent demands and necessary professional teaching reform. At present, there are still many problems that require attention and many challenges to be dealt with on how to realize the cultivation of modern journalism and communication talents through the construction of the teaching team as well as the professional teaching reform.

\section{Funding}

This paper is the research progress of the project - "Research on Curriculum Reform and Practice of Journalism and Communication Major in Newly-established Colleges and Universities under the Background of "New Liberal Arts"' - supported by the Key Research Base of Humanities and Social Sciences of Higher Education in Sichuan Province, which is the Research Center for Reform and Development of Newly-Established Colleges and Universities (Project Number: XJYX2021B13), and it is the result of the special project of teaching team construction of Sichuan University of Media and Communications in 2020 (Sichuan University of Media and Communications [2020] No. 61). 


\section{Disclosure statement}

The authors declare that there is no conflict of interest.

\section{References}

[1] Yuan K, Jiang Z, Liu C, 2020, New Era, New Demand and New Liberal Arts -- Exploration and Practice of New Liberal Arts Construction in Shandong University. China University Teaching, 2020(07): 67.

[2] Zhang K, 2019, On Teaching Team Construction of Journalism Major in Universities. News \& Writing, 2019(08): 68 .

[3] Zhou M, Guo B, 2021, Current Situation and Reform of Core Curriculum of Journalism Under the Background of New Liberal Arts -- Based on the Content Analysis of Undergraduate Training Programs in 55 Universities. Review of Journalism and Communication, 74(06): 20.

[4] Su Y, Dai H, Zhang Y, 2020, The Development Path Selection of Traditional Media in the New Media Environment. Research on Communication Power, 4(15): 46.

[5] Xue P, 2016, Research on Teaching Supervision Mode and Evaluation Index System of TCM Colleges and Universities, Beijing University of Chinese Medicine, Beijing.

Publisher's note

Bio-Byword Scientific Publishing remains neutral with regard to jurisdictional claims in published maps and institutional affiliations. 